Religious and Cultural Studies

\title{
The Concept of Atonement in the Old Testament, Greco-Roman World and the New Testament
}

\section{Ubong Ekpenyong Eyo ${ }^{1}$}

${ }^{1}$ Department of Religious and Cultural Studies. University of Calabar, Nigeria.

\section{Article History \\ Received: \\ 13.07.2020}

Revised:

29.08 .2020

Accepted:

30.09 .2020

*Corresponding Author: Ubong Ekpenyong Eyo

Email:

ubongeyo@yahoo.com

This is an open access article, licensed under: $\mathrm{CC}-\mathrm{BY}$-SA
Abstract: The Concept of Atonement has been an old concept in the biblical כפר werld. The Old Testament speaks of it using mainly the Hebrew word $(\mathrm{kphr})$, with its attendant various implications. This concept wasn't alien in the Greco-Roman world which formed part of the New Testament background. The New Testament writers pushed the concept of atonement beyond the level of animal sacrifice in the Old Testament, and the gods allowing themselves to be reconciled to sinful humanity in the Greco-Roman religious context, to the point of Jesus Christ being viewed as the Lamb of God, i.e. both the sacrificial lamb and the priest that offers the sacrifice. In this way, Christ is presented both as the offering and the offeror. The New Testament uses two main Greek words $\kappa \alpha \tau \alpha \lambda \lambda \alpha \gamma \eta$ / (katallage) and i $\lambda \alpha \sigma \mu$ ó (hilasmos) in driving home this important concept which stems from God's love towards the creation and results in forgiveness, restoration of estranged relationship, maintenance of divine justice and expression of divine mercy. The work used content analysis method of research and comparative theory in the study of religion in dealing with the subject of atonement in the Old Testament, Greco-Roman Context and the New Testament. Significantly, the work draws a thread of thought from Old Testament through Greco-Roman thought on atonement to that of the New Testament. It therefore also serves a point of comparative religious study of this thought among these three world views.

Keywords: Atonement, Greco-Roman World, New Testament, Old Testament, Reconciliation. 


\section{Introduction}

The concept of atonement runs through all the major religious thoughts of the world [1]. The Old Testament Judaism, the Greco-Roman world context and the New Testament all have their various views of this all-important concept which is the meeting point between sinful humanity and God. All through the ages, humankind being estranged in their relationship both vertically and horizontally seeks ways of getting back to God in a proper relationship, while at the same time longing for a sustainable relationship among themselves. This paper seeks to present the concept of atonement from the Old Testament, Greco-Roman and the New Testament perspectives, and then draws a conclusion from these different perspectives.

\section{Definition and Word Study of Atonement}

Down through the ages, the work of Christ has been associated with the word 'atonement'. According to Morris, "the word atonement is one of the few theological terms which is derived basically from Anglo-Saxon. It means 'making at one' and points to the process of bringing up those who are estranged into a unity" [2]. Atonement therefore presupposes a separation or alienation that needs to be overcome. As a term expressing relationship, it is tied closely to such terms like reconciliation and forgiveness. This leads to the definition given by Richards that atonement is, "the act of making amends, paying for the wrong or restoring harmony between persons who have been at odds" [3].

The word atonement either as a noun or verb 'atone' appears many times in the Old Testament, especially in the Pentateuch and is "derived from the Hebrew root כפר (kphr)" [4], but "it appears once in the New Testament i.e. Rom 5:11 (KJV) in a noun form where other versions translate the word $\kappa \alpha \tau \alpha \lambda \lambda \alpha \gamma \eta$ / (katallage) as reconciliation" [5]. In the New International Version and Revised Standard Version, there appears twice the compound word 'atoning sacrifice' (1Jn 2:2; 4:10) which is translated from the Greek noun i $\lambda \alpha \sigma \mu$ ó $\varsigma$ (hilasmos) as 'propitiation' by King James Version, New American Standard -Updated Bible, Amplified Version etc., while Revised Standard Version renders it as 'expiation'. These two Greek words will be further looked into later.

כפר $(\mathrm{kphr})$ is obscure, but the various Semitic analogies do not permit us to make a definitive distinction between 'to cover' and 'to wash away." There are Semitic analogies for regarding forgiveness of sins both in terms of covering and in terms of washing away. In the cultic term kuppuru in the expiation ritual of Babylon has a similar sound to כפר (kphr), and have the same root also; and it yields the sense, not only of 'to cover,' but of 'to wash,' 'to set aside,' 'to cancel' etc. Hence, Fausset gives the meaning of the word as, "to cover upon, which expresses the removing utterly out of sight the guilty of person(s) or thing(s) by a ransom, satisfaction or substituted victim" (1994:60). Strong further attested that the term means figuratively 'to condone', 'to placate' or 'conceal' - appease, make atonement, cleanse, disannul, forgive, to be merciful, pacify, purge (away), put off; (make) reconciliation" (2006:89). This may have accounted for why this word is linked with "the Akkadian word 'kupuru' which has the sense of 'to rub' or 'to erase"' (Eyo, 1999:16). In the Old Testament, this word is applied to the atonement or reconciliation between God and humankind.

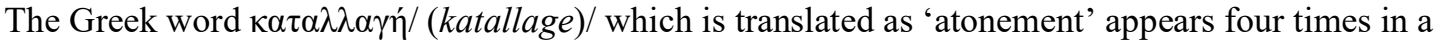
noun form in the New Testament (i.e. Rom $5: 11 ; 11: 15 ; 2$ Cor $5: 18,19)$ and in the verb form $\kappa \alpha \tau \alpha \lambda \lambda \alpha \dot{\sigma} \sigma \omega$ (katallasoo) sixty-four times" [4]. The compound verb appears in the New Testament only in the Pauline corpus where it is used once for human relationship (1Cor 7:11) and fifty-four times for God-humankind relationship (see Rom 5:19; 2Cor 5:18 etc). It means to change mutually and is used figuratively to compound a defence, reconcile, restore to (divine) favour, atonement, reconciliation etc. Synonymously, it is used figuratively in the exchange of hostility, anger or war for friendship, love and peace. At such points of usage, it denotes reconciliation in the human and political realm.

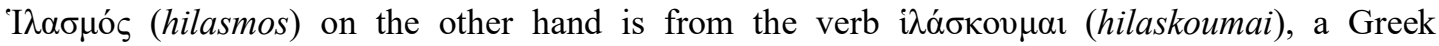
deponent verb which means "to bring about forgiveness, take way, deal mercifully with and used passively for to "be merciful or have mercy" (Aland, 1994:86). The same word is also used for expiation and propitiation or turning away (aside) God's wrath (see Heb 2:17). In the Septuagint (LXX), it is used for 'propitiation' or pertaining to expiation (see Exod 25:16; 4 Macc. 17:22).

Summarily, the word 'atonement' whichever way it may be used carries the undertone of putting an end to enmity, turning way of wrath, reconciliation and a complete restoration of broken relations among other things. Though it appears many times in the Old Testament and very few times in the New Testament, its fundamental concepts are scattered throughout both Testaments. 


\section{The Old Testament Concept of Atonement}

The account of the fall of humankind and its consequences show the displeasure of God over sin as it puts a separation between the Creator (God) and the creation (humankind) (Bruce 2017). This separation is attested to by Isaiah among other writers in the Old Testament, when he said, "not that the hands of the Lord are too short to save, but your iniquity has put a separation between you and God" (Isa. 59:1). Sin is thus a separation from God and an offence against God. It can only be cleansed by an act of atonement. There was still need to end the hostility between God and humankind; abate God's anger; and forgiveness and reconciliation to be effected because of the fall of humankind. God spearheaded this by not only coming back to look for the lost Adam and convicting humankind of the act of rebellion, but by making garments of skin for Adam and his wife and clothing them (Gen 3:21). If this was a way of purging, cleansing, concealing humankind's sin and reconciling humanity to God, then it could be probably said that God did atone for the sin of the fallen humanity. This shows that the act of reconciliation or atonement proceeded from God and not from humankind. This is an important point to note.

The Old Testament theology presents God and humankind as being hopelessly estranged due to human sinfulness and there is no way back to God from humankind's side. It then resides with God who has the way to humankind through atonement. Hence God said to the Israelites, "I have given it for you upon the altar to make atonement for your souls" (Lev. 17:11). God did not only give them the notion of atonement but also the procedure of fulfilling it by appointing "sacrifice as the divine way of securing atonement not because of any value inherent in the sacrificial victim" (Morris 1993: 104).

The first step in this procedure was the selection of a proper animal without defect - an animal(s) suited for atonement (Lev 4:3; $23: 28,32$; Exod. 29:1, etc.). The unblemished nature of the victim here is the necessary ingredient for the atonement, for it indicates the necessity of perfection. Youngblood states that, "the perfection of the animal symbolized the devotion of the offerer as he presented his gifts of life to God and reminded him of his own impurities as he sacrificed a spotless substituted life" (1997:295). This unblemished nature of the victim is also to be seen in the suffering servant of Isa $52: 13 ; 43: 12$, where he is described as one who "had done no violence nor was nay deceit found in his mouth" (Isa 53:9). The victim must also cost the offferer something, because atonement is not cheap, since sin is never taken lightly.

The second aspect of this concept was in Aaron laying his hands on the head of the scapegoat confessing over it all the wickedness and rebellion of the Israelites - all their sins and putting them on the goat's head (Lev 16:21). This symbolizes the transfer of sin from the offerer to the sacrificed, who is to carry the $\sin (\mathrm{s})$ to a solitary place. Thus the sins were never to be remembered. It is on this same vein that the "iniquity of us all" was laid on the suffering servant by the Lord (Isa 53:6). This concept may have been in the mind of Peter when he described Christ as the one who "bore our sins in his body on the tree, that we might die to sin and live to righteousness" (1Pet. 2:24). John may also have been possessed with this thought when he said of Jesus, "look the Lamb of God, who takes away the sin of the world" (Jn. 1:29).

The third aspect and the most important was the slaughtering of the animal. This symbolized the profound truth that sinners are only worthy of death. In this way, the victim therefore fulfils a double rite; it symbolizes the life of the guilty one, and its death symbolizes the death which is the punishment for sin. But the victim is at the same time the intermediary by which God communicates his life to the sinner [6].

Therefore, the essential point about the sacrifice is not the death of the victim, but the offering of its life on whose account the victim was offered. With such a preposition, the Epistle to the Hebrews point out that, "without the shedding of blood there is no forgiveness of sin" (Heb. 9:22). Thus throughout the Old Testament period, the blood of the sacrificed animal was the divinely appointed agency that symbolized the removal of sin. This was the typology of Christ's blood which Johannine Epistle states that, "the blood of Jesus his Son cleanses us from all sin" (1Jn 1:7)

The concept of atonement was so important to the Israelites that the tenth day of the seventh month yearly was set aside as the Day of Atonement - 'Yom-Kipur'. It was observed as the most solemn holy day where all work was forbidden, and all people expected to hold a strict fast. This day served as a reminder to the Israelites that all daily, weekly and monthly sacrifices made at the altar of burnt offering were insufficient to atone for sin. It is the ritual of this day that Hebrews' Epistle interprets "as a type of the atoning work of Christ, emphasizing the perfection of the latter by contrast with the inadequacy of the former" [7]. 
There are other forms of atonement apart from that of the cultic which are alluded to in the Old Testament, e.g. that of Moses interceding for the Israelites (Exod 32:30-32). It is eloquently stated in Ezek. 18:20 that, "the soul who sins is the one who will die", but that God permitted the death of a sacrificial victim to substitute for the death of the sinner was an act of God's grace.

Summarily, the following facts can be alluded to in respect of the concept of atonement in the Old Testament:

1. That atonement in the Old Testament was necessitated by the fact of human sin

2. That the act of atonement proceeds from God and not from human being

3. That in this act, the offeror identifies himself/herself with the fate of the substitute whose life is offered on behalf of the offerer

4. That atonement requires the blood of a substitute

5. That atonement is regarded as a means "employed by God for the purpose of forgiveness, for the healing of the infringements of the covenant" [5]

6. That after a successful atonement, the offerer is no more held guilty, the broken fellowship with God is completely restored as far as the $\sin (\mathrm{s})$ which has been atoned for is/are concerned. Thus God's justice will not demand twice the penalty of sin from the offerer and then from the substituted victim, for the life of the offerer is normally spared.

\section{The Greco-Roman Concept of Atonement}

The concept of atonement was not totally absent in the Greco-Roman world which is one of the background contexts of the New Testament. Within this context, "i $i \alpha \sigma \mu$ ó $\varsigma$ (hilasmos) [formed from

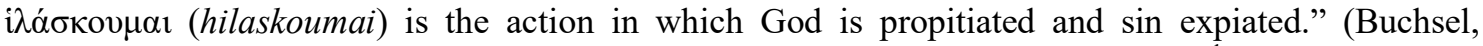
electronic copy). It is "only in a single reference in an Egyptian papyrus of the $2^{\text {nd }}$ century AD does the word have a meaning of propitiatory significance" [8]. In respect to i $\lambda \alpha \dot{\sigma} \sigma o v \mu \alpha l$ (hilaskoumai), $i \lambda \lambda \alpha \sigma \alpha \omega$ (illasaoo) which designates reconciliation in the human or political realm, it was used more in the secular world with a little religious undertone. An interesting special case is "Plutarch's designation of Alexander the Great as the reconciler of everything sent by God to unite humanity into the world-state" [9]. Plutarch, views the concept therefore as both cultic propitiation of the gods and expiatory action in general.

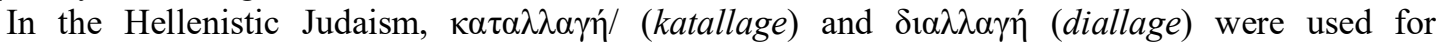
relationship between God and God's people. The initiative here springs from man towards God. This was done through prayers, repentance etc. Thus Balz quoting Josephus wrote that the "deity allows himself to be easily reconciled by those who confess and repent. But he also knows that there are instances in which God does not allow himself to be reconciled" [10].

\section{The New Testament Concept of Atonement}

As noted earlier, the word atonement is a rare word in the New Testament, but the concept of God sending Jesus Christ to redeem the world as Morris rightly puts it that, "throughout the NT it is clear that it is what God has done in Christ that enables sinners to approach him and enter into his blessing now and in the hereafter" [7]. Grudem speaks of it as "the work Christ did in his life and death to earn our salvation" [11]. Viewed as the fulfilment of the priestly office of Jesus, the Hebrews Epistle carried over from the Old Testament the concept of atonement and sees Jesus as both the High Priest and the lamb. This act of atonement was what Christ did on the cross - his whole mission. In most theological circles, atonement is thus considered as being synonymous with the death of Christ.

The moving cause of atonement from the New Testament perspective is due to the fact that, "all have sinned and fall short of the glory of God" (Rom 3:23). The consequence of this universality of sin caused by Adam is universal death for all Adam's posterity (1Cor 15:22). This is manifested in the humanity being enslaved by $\sin$ (Jn 8:34), living under the law (Rom 7:23), living in enmity between God and humankind, thus giving rise to hostility on both horizontally and vertically (Rom 8:7; Tim 3:2; Titus 3:3). This leads to God's wrath and judgement on humanity which led Paul to say that sinners are object of God's wrath (Eph 2:3) and judgement (Rom 1:24). The resultant effect of this death which is the wages of sin (Rom 6:23) and the strained relationship between God and humanity who is in a desperate situation; there is no way back to God from human side. Note Pauline expression here and the usage of the word 'wage' signifying the sense of a labourer receiving his/her due after labour. No one will be happy if after labour, his/her wage is not paid. It is therefore the 
worker's (sinner's) right to receive his/her wage, it will be wrong for one not to be paid his/her due. So in this way, God paying the sinner's wage does not make God a wicked being.

Indeed, Sproul while commenting on Jonathan Edward's sermon titled, 'Sinners in the Hand of an Angry God' said, "if the life of God can be exposed to sinners even for one second, they could have killed God because of their extreme hostility to God". This shows that from human's angle, there can be no possible hope of reconciliation but perpetual hostility towards God. This is sequel to the total depravity of humanity who cannot willingly do anything to salvage the hopeless and helpless situation. It is in the light of this that Augustus Toplady (1740-75) in one of his hymns said,

Not the labours of my hands

Can fulfil thy law's demands

Could my zeal no respite know

Could my tears forever flow

All for sine could not atone

Thou must save and thou alone (Revised Church Hynmary, 413).

On the above note, the writers of the New Testament, especially John, pegs the moving cause of atonement to God who "For God so loved the world that he gave his one and only Son, that whoever believes in him shall not perish but have eternal life." (John 3:16 c.f. 1Jn 4:9-10). Love here is not an arbitrary one but that which is the very nature of God. It connotes God's grace and unconditional love based not on any inherent good thing on the side of the recipient(s). The second moving cause of atonement according to the New Testament is the good pleasure (will) of God to save sinners by a substitutionary atonement, On this note, Paul said, "it was the good pleasure of the father that in him (Christ) should all the fullness dwell; and through him to reconcile all things unto himself ... by making peace through his blood shed on the cross" (Col 1:9-20). He further added that Christ "gave himself for our sins, that he might deliver us out of this present evil world according to the will of our God and Father" (Gal 1:4).

It is good to point out that God is a Just God who both advocates and maintains justice. By God's justice, sinners deserve to die, and the New Testament concept of atonement bears eloquent witness to this as the death of Christ (the 'animal' victim) symbolizes the death of the offerer or one who is being offered on his/her behalf (sinner). Hebrews explains this by saying that "without the shedding of blood (death), there is no forgiveness of sin" (Heb 9:22). Hence if God must forgive sinners, God's righteous judgement must be maintained. God's love is not blind that God abrogates, contradicts or makes nothing of God's existing law. So God decided to maintain God's righteousness by making Christ to die in the place of sinners and to obtain their forgiveness. The New Testament Scripture affirms this when it says that God presented him (Christ) as a sacrifice for atonement, through faith in his blood and that God did this to demonstrate God's justice (Rom 3:25). Summarily therefore, the moving causes of atonement in the New Testament are God's unconditional love, good pleasure, justice and righteousness.

Although the New Testament also points out that atonement was absolutely necessary, it was not hypothetically necessary as Athanasius, Augustine and Anselm said. God's law must be maintained, for God cannot break God's word in respect of the death penalty for sin - the law demands life as a substitute for a sinner's life. Hence Hodge painstakingly points out in line with the following scriptures Lk. 24:26; Heb. 2:10; 4:22-23; 8:3 that, the sacrifice of Christ "would be painfully irrelevant if it were short of absolute necessity in relation to the end designed to be attained - that unless it be indeed the only possible means to the salvation of sinful man. God surely would have his Son a wanton sacrifice to a bare point of will" [11].

The atoning work of Christ apart from revealing God's love for humankind, was a substitutionary death; it was vicarious in nature. He was a substitute in place of sinful humanity. Hence Christ said, for even the Son of man did not come to be served, but to serve and give his life $\lambda \hat{\tau} \tau \rho o v \dot{\alpha} v \tau i$ $\pi \mathrm{o} \lambda \tilde{\omega} v$

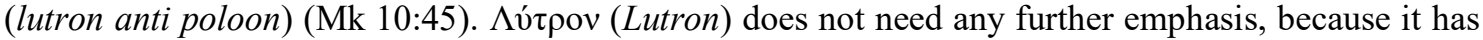
been taken care of already in this work. The word $\alpha v i$ (anti) when used with a noun genitive case means, 'for', 'in place of', or 'on behalf of'. Since $\pi \mathrm{o} \lambda \tilde{\omega} v$ (poloon) here is in genitive case, it therefore means that Christ was a substitute or ransom 'for', 'in place of', or 'on behalf of' many whom he died in their place.

Christ death was also representative in nature - he did not only die 'for sin' but 'for us'. Hence, he was the representative of those he died for as he hung on the cross. This is expressed in 2Cor 5:14 and 1Jn 2:1ff, a thought which is held more highly in the Hebrew Epistle. Christ atonement was sacrificial 
in nature, hence Paul wrote his epistles that "Christ our Passover lamb has been sacrificed" (1Cor 5:7); "just as Christ loved us and gave himself up for us as a fragrant offering and sacrifice to God" (Eph. 5:2). This was also the views of Peter and John in 1Pet 1:19 and Jn. 1:29 respectively.

As the curtain draws over this section, it is good to note the achievements of Christ's death, i.e. the needs which Christ has met for sinners through his death. These are [11]:

Sacrifice : That he died a sacrificial death in the place of the death penalty for sin. As the lamb was sacrificed in the Old Testament concept of atonement, so is Christ sacrificed for sin in the New Testament (see Heb 9:26).

Propitiation : As noted earlier, due to sin, humankind was an object of God's wrath, but by Christ's atonement, Christ has removed that wrath of God. Hence, the New Testament speaks of Christ as "the propitiation for our sins" (1Jn 4:10 NASB)

Reconciliation : The separation, strained and hostile relationship which existed between God and humanity has been bridged through Christ's death. Paul says that God "reconciled us to himself through Christ" and further emphasised "that God was reconciling the world to Himself in Christ not counting man's sin against them" (2Cor 5:18-19).

Ransom : A sinner is in bondage both to sin and the kingdom of Satan; this makes him to do the will of his master, the devil. By Christ's death, a sinner has been redeemed from this bondage. Thus Hebrews says, "when Christ came, he died and so delver all those who through fear of death were subject to lifelong bondage (Heb. 2:15)".

With the above achievements by God through Christ for sinner, Henry F. Lyte (1793-1847) greatly appreciated God in a song of praise saying,

Praise, my soul the King of heaven;

To His feet thy tribute bring;

Ransomed, healed, restored, forgiven,

Who like me His praise should sing?

Praise Him! Praise Him!

Praise Him! Praise Him!

Praise the everlasting King (Revised Church Hymnary 27 v. 1).

The New Testament affirms that the atoning work of Christ comprises of both his sacrificial death and his intercessory work (1 Jn 2:1-2; Jn 17). Berkhof rightly pointed out that, while [the] sacrificial work of Christ was symbolised primarily by the priestly function at the brazen altar and the sacrifices that were brought upon Christ, His intercessory work was prefigured by the daily burning of incense on the golden altar in the Holy place [10].

The subject of Christ's intercession is not the focal point of this work, but it is good to note that Christ's intercession was/is efficacious and complements his redemptive priestly work. They are equal both in purpose and extent. It is therefore good to conclude that in the New Testament opinion, the atonement of Christ was superior to that of the Old Testament - purposeful, complete and perfect. This was the reason why Jesus used the word $\tau \varepsilon \tau \varepsilon \dot{\lambda} \varepsilon \sigma \tau \alpha l$ (tetelestai) in Jn 19:30 while on the cross. It is good to note that the word $\tau \varepsilon \tau \varepsilon \dot{\lambda} \varepsilon \sigma \tau \alpha$ (tetelestai) which is translated as "it is finished' is from the verb $\tau \varepsilon \lambda \dot{\varepsilon} \omega$ (teleo) which means "to end, i.e. complete, execute, conclude, and discharge (a debt)" [12] and it is used in the perfect tense. Wheeler, a Research Professor on Biblical languages rightly points out that, perfect tense in Greek language speaks of "a condition resulting from an anterior occurrence. The result of the occurrence is seen to be 'present' or simultaneous with the time of speaking" [13]. The general meaning of the Perfect Tense in Greek language involves three elements which combine to produce the basic sense, and one of such element is the 'action element' which indicates an aspectfeature of summary viewpoint concerning an occurrence. Here the "type of action is viewed as a whole which is concluded, not as on-going or as an analysis of its particulars" [13]. Christ's word here speaks of an action which is done once perfectly and cannot be repeated nor nullified. This is corroborated by the writer of the Hebrew Epistle in Heb. 10:1-18. Such perfect atonement brings reconciliation, propitiation, redemption etc. in respect of God-humankind relationship. Hence it could be vividly said that according to the New Testament Concept of atonement, Christ made a perfect atonement on behalf of all those he died for. 
There is therefore no condemnation or dread of eternal damnation. Charles Wesley expressed this in one of his great hymns,

No condemnation now I dread;

Jesus, and all in Him is mine!

Alive in Him, my living Head,

And cloth in Righteousness divine,

Bold I approach the eternal throne,

And claim the crown, through Christ my own ( $\mathrm{RCH} 110)$

\section{Conclusion}

The concept of atonement does not only have religious significance but also have social implications which need to be further explored in the sphere of social interaction between the humans. In all the three religious thoughts $\mathrm{x}$-rayed above, atonement is a common concept wherewith God reconciles God's self to sinful humanity, and once atonement is given, forgiveness and reconciliation cannot be withheld. The climax of atonement in the biblical sense is Jesus Christ's self-sacrifice on behalf of the world. The extent of the application of Christ's death (atonement) needs further studies.

\section{References}

[1] M. F. Shroff, The atonement. World Literature Today, vol. 89, no. 1, pp. 17-19, 2015. doi: 10.7588/worllitetoda.89.1.0017.

[2] L. L. Morris, 'Atonement' in Douglas, J. D. \& co (ed.), New Bible Dictionary, Leicester: IVP, 1993.

[3] L. O. Richards, 'Atonement' in Richards, L. O. \& co (ed.), New Zealand: Kingsway Publication, 1984.

[4] J. Herrman, 'Expiation and Forms of Expiation in the Old Testament.' in Kittel, Gerhard \& Frederick, G. (Ed), Theological Dictionary of New Testament. Vol.111, Michigan: Wm. B. Eerdmans Publishing Co, 1989.

[5] W. Echrodt, Theology of the Old Testament vol. 2, London: SCM, 1982.

[6] E. Jacob, Theology of the Old Testament, vol. 2, London: SCM, 1982.

[7] L. L. Morris, 'Atonement' in Ferguson, S. B. \& co (ed.), New Dictionary of Theology, Leicester: IVP, 1994.

[8] U. Eyo, The Extent of Christ's Atonement in Johannine Literature, Unpublished Bachelor Degree Thesis, Department of Religious Studies, Nigeria: University of Jos, 1999.

[9] H. Balz, and J. D. Schneider, Evangelical Dictionary of the New Testament vol. 2, Michigan: IVP, 1991.

[10] L. Berkhof, Systematic Theology, Michigan: Grand Rapids, 1991.

[11] W. Grudem, Systematic Theology: An Introduction to Biblical Doctrine, Leicester: IVP, 1994.

[12] J. Strong, Biblesoft's New Exhaustive Strong's Numbers and Concordance with Expanded Greek-Hebrew Dictionary, Massachusetts: Hendrickson Publishers, 2006.

[13] D. M Wheeler, Wheeler's Greek Syntax Notes, Biblesoft/PC Study Bible 4/RefWorks/Wheerler. Nigeria: JSR, 2019. 